\title{
The effects of growth phase and light intensity on toxin production by Dinophysis acuminata from the northeastern United States
}

\author{
Mengmeng Tong ${ }^{\mathbf{a}, \mathbf{b}}$, David M. Kulis ${ }^{\mathbf{b}}$, Elie Fux ${ }^{\mathbf{c}}$, Juliette L. Smith ${ }^{\mathbf{b}}$, Philipp Hess ${ }^{\mathbf{c}}$, Qixing \\ Zhou $^{\mathbf{a}^{\star}}$ and Donald M. Anderson ${ }^{\mathbf{b}}$ \\ a Key Laboratory of Pollution Processes and Environmental Criteria (Ministry of Education), College of \\ Environmental Science and Engineering, Nankai University, Tianjin 300071, China \\ ${ }^{\mathrm{b}}$ Woods Hole Oceanographic Institution, Woods Hole, MA 02543, USA \\ ${ }^{c}$ Marine Institute, Rinville, Oranmore, Co. Galway, Ireland \\ *: Corresponding author : Qixing Zhou, email address : zhouqx@nankai.edu.cn
}

\begin{abstract}
:
For many years, the study of toxic Dinophysis species was primarily restricted to field populations until it was recently demonstrated that some of these organisms can be mixotrophically cultured in the laboratory with the ciliate prey, Myrionecta rubra, which had previously been fed with cryptophytes of the genus Teleaulax and Geminigera. Here we investigated the influence of growth phase and light intensity on the production of diarrhetic shellfish poisoning (DSP) toxins and pectenotoxins (PTXs) in cultures of Dinophysis acuminata from the northeastern United States. The cell toxin content of okadaic acid (OA), dinophysistoxin-1 (DTX1), pectenotoxin-2 (PTX2), and the okadaic acid diol ester (OA-D8) varied significantly with growth phase under all light treatments, at $6{ }^{\circ} \mathrm{C}$. Each toxin quota remained low during middle and late exponential phases, but significantly increased by mid-plateau phase. DTX1 and OA-D8 were variable through plateau phase, while OA and PTX2 significantly decreased as the culture aged. Although maximum toxin content was not achieved until middle plateau phase, the rate of toxin production was generally greatest during exponential growth. The low and relatively constant cellular toxin levels observed during exponential and early-plateau phase indicate a balance between toxin production and growth, whereas in the middle-plateau phase, toxin production continues even though the cells are no longer capable of dividing, leading to higher toxin quotas. Light was required for Dinophysis growth and the production of all toxins, however, there was no significant difference in growth rates or toxin quotas between the higher light treatments ranging from 65 to $300 \mu \mathrm{mol}$ photons $\mathrm{m}^{-2} \mathrm{~s}^{-1}$. These results demonstrate that DSP production in D. acuminata is constitutive, and that specific toxins are differentially produced or accumulated during the cells' growth phase, possibly in response to changes to their environment.
\end{abstract}




\section{Research highlights}

OA, DTX1, PTX2, and OA-D8 toxin quota remained low content during middle and late exponential phases, but significantly increased by mid-plateau phase. DTX1 and OA-D8 were variable through plateau phase, while OA and PTX2 significantly decreased as the culture aged. The rate of toxin production was generally greatest during exponential growth. A balance between toxin production and growth of Dinophysis during exponential growth, but unbalance during plateau phase, leading to higher toxin quotas. Light was required for Dinophysis growth and the production of all toxins, however, there was no significant difference in growth rates or toxin quotas between the higher light treatments ranging from 65 to $300 \mu \mathrm{mol}$ photons $\mathrm{m}^{-2} \mathrm{~s}^{-1}$.

Keywords : Diarrhetic shellfish poisoning (DSP); Dinophysis acuminata; Dinophysistoxin (DTX); Growth phase; Light; Okadaic acid (OA); Pectenotoxins (PTXs)

\section{Introduction}

Several species within the dinoflagellate genus Dinophysis are responsible for the diarrhetic shellfish poisoning (DSP) syndrome. Toxins from these organisms accumulate in shellfish and threaten public health and fisheries resources in many parts of the world (Yasumoto et al., 1980; Hallegraeff and Lucas, 1988; Lee et al., 1989; Van Egmond et al., 1993; Hallegraeff et al., 2003; FAO, 2004). DSP toxins are heat-stable polyethers a 1 nd lipophilic compounds which include okadaic acid (OA), the dinophysistoxins (DTXs) and their derivatives (Yasumoto, 1990; FAO, 2004). The pectenotoxin group (PTXs) is commonly quantified and reported with DSP toxins as they are usually co-produced within the same organisms; however, the mode of toxicity for PTXs is still being elucidated.

Globally, DSP is common, with documented cases occurring in Europe, South Africa, Central and South America, along the Gulf of Mexico coast of North America, in Asia and Oceania (Van Egmond et al., 1993; FAO, 2004). The toxin content of Dinophysis spp. in field assemblages varies spatially and temporally (Andersen et al. 1996, Cembella, 1989, Lee et al., 1989, Masselin et al., 1992, Suzuki et al., 1998, Lindahl et al., 2007). For example, Lindahl et al. (2007) reported that DSP toxin production by $D$. acuta and $D$. acuminata was significantly different between the outer archipelago and a semienclosed fjord system on the Swedish west coast, while in Mutsu Bay, Japan, the cellular content of PTX2 and DTX1 in D. fortii varied from $42.5 \mathrm{pg}$ cell-1 to $182 \mathrm{pg}$ cell-1, and $13.0 \mathrm{pg}$ cell-1 to $191.5 \mathrm{pg}$ cell-115, respectively, over multiple years (Lee et al., 1989; Suzuki et al., 1998).

The situation in North America is particularly interesting. As opposed to other coastal areas around the world where Dinophysis spp. cause frequent toxic blooms, there are only a few documented cases of DSP toxin accumulation in North American shellfish that have been attributed to Dinophysis (Tango et al., 2004; Campbell et al., 2010). Our research group previously verified that Dinophysis acuminata from Massachusetts, USA can produce DSP toxins and PTXs (Hackett et al., 2009). DTX1, 
1 OA and an OA diol ester, OA-D8, as well as PTX2, PTX2 seco-acid (PTX2 sa), and a hydroxylated PTX2 (with an identical mass spectrum to PTX11 but different retention time) were detected in this $D$. acuminata culture.

Field observations assessing the impact of environmental conditions on population dynamics have found that $D$. acuminata species are tolerant of a wide range of temperature, salinity, and light conditions in varied geographical locations, indicating that it is a cosmopolitan species (Reguera et al., 1993, Nishihama et al., 2000, Hoshiai Gen-ichi et al., 2003, Koukaras and Nikolaidis, 2004, Setälä et al., 2005, Gisselson et al., 2002). Reguera et al. (1993) reported that D. acuminata, in Galician waters occurred when the temperatures ranged between 12.5 and $22^{\circ} \mathrm{C}$ and salinity between 28 and 34.5\%o. Similarly, Hoshiai Gen-ichi et al. (2003) reported that D. acuminata in northern Japan was generally associated with average temperatures of $17.3 \pm 3.9^{\circ} \mathrm{C}$ and salinity of $32.70 \pm 0.85 \%$. High concentrations of D. acuminata have also been associated with temperatures as low as $5-8^{\circ} \mathrm{C}$ along the northwest coast of Hokkaido, Japan (Nishihama et al., 2000) and $11.5-12.5^{\circ} \mathrm{C}$ in Greek coastal waters (Koukaras and Nikolaidis, 2004). In Baltic waters, D. acuminata could tolerate low salinity $(5-10 \%)$, low light levels $\left(\sim 20 \mu \mathrm{E} \mathrm{m}{ }^{-2} \cdot \mathrm{sec}^{-1}\right)$ and low temperature $\left(5^{\circ} \mathrm{C}\right)$ (Setälä et al., 2005). Gisselson et al. (2002) found that the maximum density of $D$. norvegica was at $22 \mathrm{~m}$ depth with a corresponding irradiance of $7 \mu \mathrm{mol} \mathrm{m} \mathrm{m}^{-2} \cdot \mathrm{sec}^{-1}$. While many field studies have focused on the ecology, behavior, toxin content, and genetic diversity of Dinophysis populations, much remains unknown about this genera; for many years, researchers were unable to successfully maintain laboratory 
1 cultures. This obstacle was overcome when Park and co-authors (2006) successfully

2 cultured an isolate of D. acuminata by providing the ciliate prey Myrionecta rubra

3 (=Mesodinium rubrum), which, in turn, was fed the cryptophyte Teleaulax $\mathrm{sp}$. As a

4 result of this culturing achievement, D. fortii (Nagai et al., 2008), D. caudata

5 (Nishitani et al., 2008a), D. acuta (Jaén et al., 2009) and D. infundibulus (Nishitani et al., 2008b) have also been successfully cultured. Researchers now have the ability to examine toxin production in Dinophysis as well as to investigate many biochemical and physiological questions that have eluded scientists for many years.

Here we examine the effect of light intensity on growth, as well as the effects of light and growth phase on the toxin production rates and the accumulation of toxins by D. acuminata.

\section{Material and Methods}

\subsection{Maintenance of $D$. acuminata, M. rubra and $G$ cryophila}

A unialgal, multi-cell culture of D. acuminata (DAEP01) was established in September of 2006 by isolating several cells from a water sample taken from Eel Pond, Woods Hole, Massachusetts, USA (ambient water temperature $\sim 18^{\circ} \mathrm{C}$ ), into a 48-well tissue culture plate. These mixotrophic cells were fed a clean $M$. rubra cell suspension (CCMP2563) which had been previously raised on G. cryophila (CCMP2564) following the protocols of Park et al. (2006) as modified by Hackett et al. (2009). M. rubra was maintained by feeding it a suspension of G. cryophila prey at the ratio of 1:10. Following complete consumption of the cryptophyte cells by $M$. 
rubra, the ciliate was fed to D. acuminata by adding $3 \mathrm{~mL} M$. rubra $(\sim 14,000$ cells $\left.\mathrm{mL}^{-1}\right)$ with $2 \mathrm{~mL}$ D. acuminata $\left(\sim 1800\right.$ cells $\left.\mathrm{mL}^{-1}\right)$ in $20 \mathrm{~mL}$ modified $\mathrm{f} / 2$ medium whereby $\mathrm{H}_{2} \mathrm{SeO}_{3}$ was added and $\mathrm{CuSO}_{4}$ was reduced to concentration of $10^{-8} \mathrm{M}$ each (Anderson et al., 1994) at $4^{\circ} \mathrm{C}$ in $\operatorname{dim} \operatorname{light}\left(\sim 50 \mu \mathrm{mol}\right.$ photons $\left.\cdot \mathrm{m}^{-2} \cdot \mathrm{sec}^{-1}\right)$ under a $14 \mathrm{~h}$ light: $10 \mathrm{~h}$ dark photocycle.

As mentioned in Hackett et al. (2009), we conditioned the Eel Pond $D$. acuminata to the low temperatures of 4 and $6{ }^{\circ} \mathrm{C}$ that were required to maintain our prey strains of Myrionecta and Geminigera, which originated in the Ross Sea, Antarctica (Gustafson et al., 2000). We were unsuccessful in isolating a temperate prey for the dinoflagellates, and so the temperature range of the experiments reported here was limited by the tolerances of the Antarctic prey.

\subsection{Toxin production by $D$. acuminata in batch culture under different light} conditions

D. acuminata cultures were grown under four different light conditions at $6^{\circ} \mathrm{C}$ : 284 (100\% light), 145 (50\% light), 65 (25\% light), and $0 \mu \mathrm{mol}$ photons $\cdot \mathrm{m}^{-2} \cdot \mathrm{sec}^{-1}$ (no light). A set of cultures were grown at $4^{\circ} \mathrm{C}$ under high light $(302 \mu \mathrm{mol}$ photons $\cdot \mathrm{m}^{-2} \cdot \mathrm{sec}^{-1}$, equivalent to the $100 \%$ light level at $6^{\circ} \mathrm{C}$ ) to be used for prey and predator controls. For each treatment, duplicate, Fernbach flasks with $1300 \mathrm{~mL}$ of f/2-Si medium were inoculated with ca. 2000 and 100 cells $\mathrm{mL}^{-1}$ of experimentally equilibrated M. rubra and D. acuminata (inoculated from plateau phase), respectively. Cell count samples were taken three times per week, beginning on Day 3, and were 
1 fixed with a 5\% v/v formalin solution (Tong et al. 2010) and enumerated in a

2 Sedgewick-Rafter chamber using a microscope at 100X.

During the course of the culture's growth, from early exponential to late-plateau phase, five samples for toxin analysis were harvested from each duplicate flask and processed separately. Beginning on Day 10, an aliquot of medium containing approximately $180,000 \mathrm{D}$. acuminata cells was passed through a $20-\mu \mathrm{m}$ Nitex sieve to collect the D. acuminata cells. Samples in the dark treatment were harvested under red light. The sieved cells were rinsed into a pre-weighed $15-\mathrm{mL}$ centrifuge tube and duplicate, $200 \mu \mathrm{L}$ aliquots were pipetted from the homogenized aliquot into separate micro-centrifuge tubes containing $1 \mathrm{~mL}$ of filtered seawater and $60 \mu \mathrm{L}$ formalin $(5 \%$ $\mathrm{v} / \mathrm{v}$ formalin) to later determine the cell density in the harvested cell concentrate. The 15-mL tube was reweighed to determine the volume of harvested D. acuminata cells, (sample weight divided by the density of seawater, $1.03 \mathrm{~g} / \mathrm{mL}$ ), centrifuged at $3000 \mathrm{x}$ g for 5 minutes and the supernatant was aspirated to a small volume $(<250 \mu \mathrm{L})$. The samples were flash frozen and stored in liquid nitrogen, and eventually shipped on dry ice for analysis at the Irish Marine Institute in Galway (MI). Control cultures of $M$. rubra containing 256,800 cells and G. cryophyla containing $1,000,000$ cells were also concentrated for toxin analysis.

\subsection{Calculation of growth rate and toxin production rate}

The average growth rates of $D$. acuminata and the ciliate prey, M. rubra, were calculated using the following formula: 


$$
\mu=\frac{\ln \left(C_{2} / C_{1}\right)}{t_{2}-t_{1}}
$$

5 of growth.

6 The toxin concentration, $\mathrm{C}_{\mathrm{t}} \mathrm{T}_{\mathrm{t}}$ (amount toxin $\mathrm{mL}^{-1}$ culture), was determined by multiplying $C_{t}\left(\right.$ cells $\mathrm{mL}^{-1}$ ) by $T_{t}$, the cellular toxin content (amount toxin cell ${ }^{-1}$ ) at

8 time t. $\mu_{\text {tox }}$, the specific toxin production rate (amount toxin $\mathrm{mL}^{-1} \mathrm{~d}^{-1}$ ) in the cultures, was calculated similarly to growth rate (i.e., between two consecutive sampling points during exponential growth phase) as follows:

$$
\mu_{o x}=\frac{\ln \left(C_{2} T_{2} / C_{1} T_{1}\right)}{t_{2}-t_{1}}
$$
To account for the effect of cell growth rates on toxin production, the net toxin production rate $\mathrm{R}_{\text {tox }}$ (amount toxin cell $^{-1} \mathrm{~d}^{-1}$ ) was determined over each growth phase in the batch-cultures using the equation (Anderson et al., 1990),

$$
R_{t o x}=\frac{\left(C_{2} T_{2}-C_{1} T_{1}\right)}{(\bar{C})\left(t_{2}-t_{1}\right)}
$$

where $\bar{C}$ is the ln average of the cell concentration,

$$
\bar{C}=\frac{C_{2}-C_{1}}{\ln \left(C_{2} / C_{1}\right)}
$$

\subsection{Toxin analysis}

Toxin sampling points were chosen based on the cultures' growth phase (middle and late-exponential phase and early, middle, and late-plateau phase) as shown in Fig. 
All cell extractions and subsequent analyses for OA, OA-D8, DTX1, and PTX2 were conducted at the MI. A detailed description of these methods is contained in Hackett et al. (2009). In brief, each sample was extracted four times, which included sonication with $200 \mu \mathrm{L}$ of methanol for $15 \mathrm{~min}$, centrifugation at $4200 \mathrm{x} \mathrm{g}$ for $5 \mathrm{~min}$, and clean-up using a spin filter $(0.2 \mu \mathrm{m})$. LC-MS/MS analyses of OA and DTX1 were performed on a 2695 Waters HPLC coupled to a triple quadrupole (TQ) Quattro Ultima mass spectrometer (Waters Micomass, UK). The separation of the compounds was achieved on a C8 Hypersil column ( $50 \times 2.1 \mathrm{~mm} ; 3.5 \mu \mathrm{m}$ particle size $)$ maintained at $25^{\circ} \mathrm{C}$ with gradient elution where phase A was $100 \%$ aqueous and phase B $95 \%$ aqueous acetonitrile, both containing $2 \mathrm{mM}$ ammonium formate and 50 mM formic acid (Quilliam et al., 2001). A noncertified reference standard for DTX1, obtained from Bluebiotek (Germany), was used to determine retention time, while OA and DTX1 were ultimately quantified against a 7-level calibration curve using an OA reference solution (CRM-OA-b) purchased from the NRC (National Research Council, -Canada). A diol ester derivative of OA, OA-D8, was not quantified but a reference solution kindly obtained from M. Quilliam was used to confirm the presence of the toxin. An internal laboratory reference solution prepared from Mytilus edulis containing OA, DTX1 and DTX2 (McCarron, 2008) was used for comparison of the retention times in the unknowns.

Analysis of PTXs was carried out by Ultra Performance Liquid Chromatography (UPLC) Acquity system (Waters, UK) in conjunction with the previously described mass spectrometer (TQ). Separation of the compounds was achieved with a C8 BEH 
1

Acquity column ( $50 \times 2.0 \mathrm{~mm} ; 1.7 \mu \mathrm{m}$ particle size $)$ maintained at $30^{\circ} \mathrm{C}$, with a gradient elution using the mobile phases described above. PTX2 was quantified against a certified standard of PTX2 (CRM-PTX2) from the NRC, Canada. A reference solution of PTX11 was obtained from C. Miles.

Toxin data are presented in various forms throughout this manuscript: toxin quota or content (toxin amount per cell), expressed as a specific toxin (e.g., OA toxin quota) or as a total value of the toxin concentration (total toxin amount per $\mathrm{mL}$ ), net toxin production rate (toxin amount per cell per day, $\mathrm{R}_{\text {tox }}$ : Anderson et al. 1990), specific toxin production rate (toxin amount per $\mathrm{mL}$ per day, $\mu_{\mathrm{tox}}$ ), and the ratio of toxin congeners to one another (e.g., OA/DTX1, PTX2/(OA+DTX1)). The ratios are used to demonstrate how these toxins vary relative to each other through the growth phases.

\subsection{Statistical analysis}

Statistical analysis (SAS software, version 9.2) was used to test for any effects of growth phase $(\mathrm{n}=24)$, light $(\mathrm{n}=24)$, or temperature $(\mathrm{n}=16)$ on toxin content in $D$. acuminata. For the analyses, toxin quotas (toxin per cell) were grouped according to the 5 designated growth phases (middle and late exponential phase and early, middle, and late-plateau phase) as opposed to the actual day of sampling as the length of the growth phases varied depending upon the treatment (Fig. 1). For the analysis of light and growth phase effects, all three light treatments at $6^{\circ} \mathrm{C}$ were included, and for the effect of temperature, the $4^{\circ} \mathrm{C}, 100 \%$ light and $6^{\circ} \mathrm{C}, 100 \%$ light treatments were 
compared.

All data sets were normally distributed, as determined by the Shapiro-Wilk test, except for three: temperature treatment for DTX1 and light treatments for OA and OA-D8. Normality was achieved for the OA and DTX1 data using Log10 and cosine transformations, respectively. OA-D8 data could not be normalized, and so, non-parametric analysis was performed as described below.

The normalized data were analyzed using Mixed Model, Repeated Measures ANOVA as this model allows for repeated measurements on the same subject and an unbalanced design; seven samples were used for the optimization of the extraction method and for LC-MS/MS method development, and therefore, were not used in the statistical analysis. These included: one of the duplicate samples for the first three time points of $100 \%$ light $6^{\circ} \mathrm{C}$ treatment, the first two time points of $50 \%$ light $6^{\circ} \mathrm{C}$ treatment, the first time point of $25 \%$ light $6^{\circ} \mathrm{C}$ treatment and the second time point of $100 \%$ light $4{ }^{\circ} \mathrm{C}$ treatment. The nonparametric, Mann-Whitney-Wilcoxon signed-rank test was used to analyze the OA-D8 data. The Sidak-Holm post-hoc model tested pairwise comparisons. Alpha was set at 0.05 for all analyses.

\section{Results}

\subsection{Effect of light and temperature on growth}

Light was required for growth of Dinophysis, as demonstrated by the "no light" treatment. Over the 17-day incubation period, D. acuminata cell concentrations remained constant (i.e., no growth) in the dark treatment while the number of $M$. 
rubra, which never increased after inoculation, declined to zero due to cell mortality (as a result of the absence of light) and grazing. D. acuminata growth was observed in the three higher light treatments, however, the average growth rates were not appreciably different $(\mathrm{p}=0.29): 100 \%, 50 \%$ and $25 \%$ (equivalent to 284,145 , and 65 $\mu \mathrm{mol}$ photons $\mathrm{m}^{-2} \mathrm{~s}^{-1}$ ), with rates of $0.19 \pm 0.02,0.19 \pm 0.01$ and $0.21 \pm 0.02 \mathrm{~d}^{-1}$, respectively (Fig. 2f). In the three higher light treatments, the ciliate prey disappeared on the $12^{\text {th }}$ day at $100 \%$ and $50 \%$ light, and on the $10^{\text {th }}$ day in the $25 \%$ light condition, giving rise to maximum Dinophysis cell densities of 2,782, 2,629 and 2,235 cells $\cdot \mathrm{mL}^{-1}$, respectively.

When comparing the two temperature treatments at $100 \%$ light, D. acuminata had a higher growth rate at $6^{\circ} \mathrm{C}, 0.19 \pm 0.02 \mathrm{~d}^{-1}$, than the control treatment at $4^{\circ} \mathrm{C}, 0.12 \pm$ $0.01 \mathrm{~d}^{-1}$. Conversely, the maximum cell concentration of D. acuminata was enhanced at $4{ }^{\circ} \mathrm{C}\left(4,218\right.$ cells $\left.\mathrm{mL}^{-1}\right)$ compared to $6^{\circ} \mathrm{C}\left(2,782\right.$ cells $\left.\mathrm{mL}^{-1}\right)$. In the $4^{\circ} \mathrm{C}$ control treatment, the M. rubra prey were consumed by Day 21 and the D. acuminata mantained exponential growth for 26 days, while at $6^{\circ} \mathrm{C}$, the prey disappeared on Day 12 and D. acuminata grew exponentially for only 17 days. The differences in the final D. acuminata cell densities, as well as the prolonged period of exponential growth, can be ascribed to the prolonged availability of food prey at its preferred lower incubation temperature.

Growth rates in the present study were generally lower than those observed in other culture studies using various light levels and higher temperatures (Table 1), but were consistent with other studies conducted in our laboratory using similar culturing 
conditions (Hacket et al. 2009; unpublished data).

\subsection{Toxin analyses}

Analyses of the cell extract using LC-MS/MS TQ and UPLC methods showed the presence of several DSP toxins and PTXs, including: OA, DTX1, OA-D8, and the polyether-lactone, PTX2 along with its degradation product PTX2 seco-acid (PTX2sa) and an isomer of PTX11 (Hackett et al., 2009). The isomer of PTX11 and PTX2sa data will not be presented as there was no correlation between PTX2 and PTX2sa or between the isomer of PTX11 and PTX2, suggesting that both compounds may be artifacts of the extraction method. Moreover, when detected, the concentrations of PTX2sa were 100 to 1,000 times lower than PTX2 and the concentration of the isomer of PTX11 was typically 20 to 500 times lower than PTX2, thus, their contribution to the total cellular toxin pool was minimal. The isomer of OA, DTX2, was not detected in any of the samples.

Control cultures of Geminigera and Myrionecta were also analyzed for OA, OA-D8, DTX1, and PTXs. No toxins were detected in these cultures, confirming that the measured toxins were only produced by Dinophysis.

\subsubsection{Production of DSP toxins and PTXs as a function of growth phase}

Five time points were sampled for toxin content throughout the various phases of the cultures' growth. Growth phase had a significant effect on the toxin content of DTX1, OA, PTX2 and OA-D8 in D. acuminata at $6^{\circ} \mathrm{C}$ under the three higher light 
treatments (Repeated Measures, Mixed model ANOVAs). The toxin content of DTX1, OA, PTX2 and OA-D8 was maintained at low levels (showing no significant change) through middle, and late exponential phases, but rose significantly by middle plateau phase. As opposed to DTX1 and OA-D8, for which the toxin content was typically higher but variable in late plateau phase (Fig 3g, Table 2), OA and PTX2 toxin content significantly decreased by late plateau phase to values near initial toxin quotas in mid-exponential phase $(\mathrm{p}<0.001 \mathrm{OA} ; \mathrm{p}=0.004$ PTX2; Fig 2, Table 2). There was not adequate replication to allow for the statistical analysis of growth phase effects within the $4^{\circ} \mathrm{C}$ control, but, some similar patterns of toxin accumulation and loss were observed compared to the $6^{\circ} \mathrm{C}$ treatments. The lower temperature appeared to both lengthen the exponential growth phase by 10 - 20 days and cause the peak toxin quotas to occur slightly earlier (i.e., early plateau vs. middle plateau as seen at $6^{\circ} \mathrm{C}$, Fig 2a-2e).

Although the maximum toxin content for each toxin was not achieved until middle plateau phase, the rate of toxin production (toxin per cell per day, $\mathrm{R}_{\text {tox }}$; Anderson et al. 1990) was generally greatest during exponential growth. Toxin concentrations (toxin per $\mathrm{mL}$ ) continued to increase in the cultures from mid-exponential phase to mid-plateau phase, but decreased by late-plateau phase under all conditions tested (Fig. 3b-3e). Toxin production rates $\left(\mathrm{R}_{\text {tox }}\right)$ were greatest during exponential phase, decreased by the beginning of plateau phase, and were consistently lowest between middle to late plateau phase (Fig. 3g-3j, 4b). Specific toxin production rate (toxin per $\mathrm{mL}$ per day, $\mu_{\text {tox }}$ ) had a positive linear relationship 
1 with specific growth rate $(\mu)$ during exponential phase, where toxin production

2 increased in a 1:1 ratio with growth rate (Fig. 5).

For the dark treatment, replicate samples were pooled for toxin analysis as the

4 individual cultures did not provide sufficient biomass to reach quantitation detection

5 limits. Therefore, data from this treatment could not be statistically analyzed.

6 Quantifiable levels of DTX1, OA, OA-D8, and PTX2 were measured following the

7 22-day dark incubation; however, values were lowest in this treatment compared to

8 any day during the light treatments (Fig. $2 \mathrm{~g}-2 \mathrm{j}$ ).

\subsubsection{Production of DSP toxins and PTXs as a function of light and temperature}

Light was required for toxin production at $6^{\circ} \mathrm{C}$, and as such, toxin quotas

remained low in the dark treatment. Under higher light levels, 65 - $300 \mu \mathrm{mol}$

photons $\cdot \mathrm{m}^{-2} \cdot \mathrm{sec}^{-1}$, toxin production occurred, leading to higher toxin quotas; however, there was no apparent difference in cell toxin content between these three higher light treatments (Repeated Measures, Mixed model ANOVA, Fig. $2 \mathrm{f}-2 \mathrm{j}$ ). There was also no significant difference in overall toxin content between the 4 and $6^{\circ} \mathrm{C}$ temperature treatments at $100 \%$ light, $\sim 290 \mu \mathrm{mol}$ photons $\cdot \mathrm{m}^{-2} \cdot \mathrm{sec}^{-1}$ (Fig. $2 \mathrm{~b}-2 \mathrm{e}$ ).

\section{Discussion}

Here we investigated the influence of different phases of batch culture growth, light concentration, and to a limited extent, temperature, on the production of DSP toxins and PTXs by D. acuminata from the northeastern United States. As presented 
1 in more detail below, light intensities between 65 and $284 \mu \mathrm{mol}$ photons $\cdot \mathrm{m}^{-2} \cdot \mathrm{sec}^{-1}$ had

2 no effect on the growth rate or toxin content of $D$. acuminata as results were the same

3 between these three treatments, but cultures exposed to the lowest light treatment ( 0

$4 \mu \mathrm{mol}$ photons $\cdot \mathrm{m}^{-2} \cdot \mathrm{sec}^{-1}$ ) produced no additional growth or toxins suggesting light is

5 required for both processes. However, the toxin quotas of OA, DTX1, PTX2, and

6 OA-D8 varied significantly with growth phase and toxin was always detected in the

7 cultures even when incubated in complete darkness for 17 days. The highest toxin

8 production rates occurred during exponential growth, but the most toxic cells were

9 observed in mid-plateau stage due to the cessation of cell division. DSP toxin and

PTX production by $D$. acuminata is thus constitutive and specific toxins are differentially accumulated during the cells' growth phase.

It is important to point out that the experiments presented here were conducted at

$6^{\circ} \mathrm{C}$, a temperature at the lower boundary of $D$. acuminata's observed temperature range. As the prey culture, M. rubra, established from the Ross Sea, Antarctica prefers $3-4^{\circ} \mathrm{C}$ for growth, and the D. acuminata likely prefers higher temperatures, we conducted a series of growth experiments at 4,6 , and $10^{\circ} \mathrm{C}$ to determine the maximum incubation temperature that would not overtly stress either species (Tong et al., 2010, and data not shown). D. acuminata growth rates were significantly higher at both 6 and $10^{\circ} \mathrm{C}$ when compared to $4^{\circ} \mathrm{C}$; however at $10^{\circ} \mathrm{C}$, the $M$. rubra had high mortality rates. Ultimately, $6^{\circ} \mathrm{C}$ was chosen as the experimental temperature for the current work as both species were able to tolerate the temperature and we found no significant differences in D. acuminata growth rate between the two higher 
temperatures. We would also like to mention that only intra-cellular toxin concentrations are reported here and these values may underestimate the total toxin pool in the culture if there was any loss of toxin due to cell leakage or lysis.

\subsection{Toxin production}

Many of the Dinophysis species that form blooms in North American waters are known to produce DSP toxins in other regions (e.g., D. fortii, D. acuminata, D. caudata, D. norvegica, and D. acuta; Marshall, 1996; Rehnstam-Holm et al., 2002, Lee et al., 1989). However, there are only a few documented cases of toxin production by Dinophysis spp. along the North American coastline. Plankton tow material captured during a dense bloom of $D$. acuminata in the Chesapeake Bay was found to have very low levels of OA (Tango et al., 2004) and tow material having both $D$. norvegica and D. acuminata from the Gulf of St. Lawrence, Canada, contained OA (Cembella, 1989). In 2008, a significant bloom of Dinophysis ovum, containing DSP toxins, occurred along the coast of southeastern Texas (Campbell et al., 2010). Given the presence of potentially toxic Dinophysis species and blooms in North American waters, one has to wonder why this large region has not been significantly affected by DSP outbreaks, particularly given the frequent outbreaks that occur in Europe at similar latitudes. Is this due to the specific ability of certain strains within a species to produce toxins based on their genetic makeup and expression, or do factors such as diet and environmental variables including temperature, light, salinity, and nutrients influence the degree to which DSP toxins and PTXs are synthesized within 
1 these cells? Our results suggest that the answer is likely a combination of these

2 factors.

Hackett et al. (2009) determined that D. acuminata cultures isolated from Woods Hole, MA, USA, an area with no known history of DSP toxicity, can produce DSP toxins and PTXs. Kamiyama and Suzuki (2009) determined that their D. acuminata isolated from Kesennuma Bay, Japan produced levels of cellular PTX2 (14.8 pg cell ${ }^{-1}$ ) at $15^{\circ} \mathrm{C}$ in low light $\left(15 \mu \mathrm{mol}\right.$ photons $\left.\mathrm{m}^{-2} \mathrm{~s}^{-1}\right)$ that were similar to our North American strain (19.8 $\left.\mathrm{pg} \mathrm{cell}^{-1}\right)$, but had much higher cellular concentrations of DTX1 (4.8 pg cell $^{-1}$ vs. $0.31 \mathrm{pg} \mathrm{cell}^{-1}$, respectively). In a field survey of $D$. acuminata conducted from 2000 - 2002 along the coast of New Zealand, MacKenzie et al. (2005) found that total cellular toxin levels (OA + DTX1 + PTXs) ranged from 2.8 to $33.2 \mathrm{pg} \mathrm{cell}^{-1}$ which compares well with the toxin quotas found in the $D$. acuminata cultures from this study, which ranged from 8.8 to $20.1 \mathrm{pg}\left(\mathrm{OA}+\mathrm{DTX} 1+\mathrm{PTX}_{2}\right)$ cell ${ }^{-1}$. However, the maximum cell content of OA in our batch cultures was only $0.051 \mathrm{pg} \mathrm{cell}^{-1}$, while OA in natural populations of D. acuminata ranged from 11 to $50 \mathrm{pg} \mathrm{cell}^{-1}$ from Hokkaido, Japan (Suzuki et al., 2008), 0 to 16.6 pg cell $^{-1}$ along the Swedish west coast (Lindahl et al., 2007), and 12.9 to $29.6 \mathrm{pg} \mathrm{cell}^{-1}$ in sorted D. acuminata/D. sacculus along the French coast (Masselin et al., 1992). It is not yet known whether the relatively low, but consistent, levels of OA in our experiments are due to strain variability or the laboratory culturing conditions.

\subsubsection{Growth phase effects on toxin production}


The amount of toxin produced by $D$. acuminata cells varies significantly through

the cultures' growth. In all light incubations at $6^{\circ} \mathrm{C}$, excluding the dark treatment, cellular levels of DTX1, PTX2, OA, and OA-D8 were relatively low (i.e., showed no significant change) through exponential growth, but rose significantly by middle-plateau phase. All toxins were produced at a rate similar to the growth rate during exponential phase, as shown by the relatively constant toxin content during exponential growth (Fig. 3,4$)$ and the $1: 1$ ratio of specific toxin production rate $\left(\mu_{\text {tox }}\right)$ and specific growth rate ( $\mu$, Fig. 5). Together these data suggest that growth and cell metabolism may have a role in toxin production during exponential phase. However, the significant increase in toxin content in the plateau phase demonstrates an uncoupling of toxin production from growth at this latter stage (Fig. $2 g-j$ ). More specifically, the relatively constant cellular toxin levels observed during exponential and early-plateau phase indicate a relationship between toxin production and growth (Fig. $3 f-j$ ), whereas in the middle-plateau phase, toxin production continues even though the cells are no longer capable of dividing, leading to higher toxin quotas (Fig. $2 \mathrm{~g}-\mathrm{j}$ and $3 \mathrm{~g}-\mathrm{j}$ ). This general pattern was also observed in the $4^{\circ} \mathrm{C}$ control (Fig. $2 \mathrm{~b}-\mathrm{e}$, $4 b)$.

During middle to late-plateau phase, toxin content, toxin concentrations, and toxin production rates either became variable or declined, suggesting toxins were possibly leaked into the medium or biotransformed/degraded as the culture aged (Fig. 2, 3, 4). MacKenzie et al. (2005) found significant amounts of PTX2, OA, and DTX1 dissolved in seawater samples from New Zealand containing D. acuminata, and most 
notably, the dissolved fraction increased during the decline of the bloom as a result of cellular excretion, cell lysis or predation. Similarly, significant amounts of OA and low amounts of PTX2 were also detected in seawater on the West Coast of Ireland at the decline of a mixed bloom of D.acuminata and D.acuta and were found to be evenly distributed in the water column (Fux et al., 2009). Additional experiments are underway in our laboratory to investigate the decrease in cellular toxins during late-plateau phase and the leakage of these toxins into the surrounding medium. This variation in toxin production as a result of physiological changes associated with growth phase or nutrient availability of batch cultures, termed "growth stage variability" by Anderson et al. (1990), has also been documented in other HAB species (e.g., Granéli et al. 1998). In our study, D. acuminata had maximum toxin content during early to mid-plateau phase, showing a similar pattern to another DSP toxin producer, Prorocentrum lima, from the Galician coast (Bravo et al. 2001) and Atlantic coast of Canada (Quilliam et al., 1996) that had maximum cellular OA and derivative levels during plateau phase. Kamiyama et al. (2010) showed that at higher temperatures (i.e., $10-22^{\circ} \mathrm{C}$ ), their isolate of Dinophysis acuminata significantly increased the cellular content of OA, DTX1, and/or PTX2 during exponential growth phase; this is in contrast to our results which demonstrated relatively constant toxin quotas during exponential growth despite high net toxin production rates $\left(\mathrm{R}_{\text {tox }}\right)$. Our results do agree, however, in that we both found that the specific toxin production rates $\left(\mu_{\text {tox }}\right)$ and specific growth rates $(\mu)$ were correlated during this early growth phase. PSP toxin producers Alexandrium fundyense and Pyrodinum bahamense had 
1 the highest toxin contents during exponential growth in nutrient replete medium

2 (Anderson et al. 1990, Usup et al. 1994). Pseudo-nitzschia australis accumulates

3 domoic acid (DA) early in batch culture growth, beginning in early exponential phase,

$4 \quad$ while cells of $P$. multiseries accumulated the majority of DA later, during early

5 plateau phase (Bates, 1998).

According to Lindahl et al. (2007), low cell densities of Dinophysis may have

7 elevated toxin content compared to high-density populations. In this field study,

8 where the levels of OA and DTX1 were measured in a mixture of D. acuminata and D.

9 acuta, the authors found an inverse relationship between cell density and toxin quotas, where populations at low cell abundance had the highest toxin content. No information was provided by the authors to indicate whether low cell densities corresponded to initiation or decline of the bloom. Our laboratory culture results do not support this observation, as D. acuminata cells contained the most toxin during the periods of highest cell density (early to mid-plateau phase). However, we did not analyze cells for toxin content when cell densities were very dilute such as during early exponential phase or very late plateau phase when culture cell densities were less than 500 cells $/ \mathrm{mL}$ due to biomass requirements for toxin analysis. The possibility therefore exists for enhanced cellular toxin levels in "young" or "old" low-density cells.

To investigate how toxins vary relative to each other over time, the ratio of PTX2 to OA+DTX1 was calculated; the latter two congeners were summed as they are structurally similar and are likely biosynthesized via a similar pathway. The ratios for 
our North American D. acuminata are quite high, ranging from a low of 33.8 to a high of 193.2 (Table 2). Although all toxins showed the same overall pattern in production (low through exponential phase followed by a significant increase by middle-plateau phase), the ratio of PTX2 to OA+DTX1 generally trended downward over time.

Decreases in the ratio were a result of increasing femtogram concentrations of $\mathrm{OA}+\mathrm{DTX} 1$ in the denominator as opposed to the relatively stable picogram quantities of PTX2 in the numerator. The OA+DTX1 value was driven by the higher DTX1 per cell concentrations relative to the OA per cell concentrations, as DTX1 was often 4 to 8 times higher during the growth period of D. acuminata (Table 2). From these ratios it is apparent that although the cells contained 2 to 3 orders of magnitude more PTX2 than DTX1 or OA, the latter two varied more over the growth phase of D. acuminata. Similarly, we compared the toxin quotas of OA and DTX1 over the cultures' growth. Pizarro et al. (2008) found that OA and DTX2 were strongly correlated $\left(\mathrm{p}<0.001, \mathrm{r}^{2}=0.89\right)$ and that the OA:DTX2 ratio was fairly constant at approximately 3:2 (or 1.5) during a 24 hour field study of D. acuta. In the present study, we also found a significant relationship $\left(\mathrm{p}<0.05, \mathrm{r}^{2}=0.18\right)$ between OA and DTX1 in the $D$. acuminata cell (Fig. 6), however, the correlation was not as strong as the one seen between OA and DTX2 (Pizarro et al. 2008) and our average ratio was much smaller $(0.15 \pm 0.07)$, indicating D. acuminata contained more DTX1 than OA.

\subsubsection{Toxin production as a function of light and temperature}

Light intensity had an effect on growth and toxin production with the threshold 
1 likely lying within the lower two light levels tested in our experiments $(0$ and $65 \mu \mathrm{mol}$

2 photons $\mathrm{m}^{-2} \mathrm{~s}^{-1}$ ). No growth or toxin production was observed in the dark treatment

3 and statistically indifferent levels of growth and toxin were produced under the three

4 higher light levels $\left(65-300 \mu \mathrm{mol}\right.$ photons $\left.\mathrm{m}^{-2} \mathrm{~s}^{-1}\right)$. We also found a trend towards

5 increasing toxin content, toxin concentration, and toxin production of OA, DTX1 and

6 OA-D8 with reduced light intensity. The low light levels may even be preferred by

7 this mixotrophic dinoflagellate as Kim et al. (2008) found that the growth rate of $D$.

8 acuminata is constant between $30-200 \mu \mathrm{E} \mathrm{m}^{-2} \mathrm{~s}^{-1}$, but becomes markedly slower at

9 lower light levels. In our study, although not significant, reduced light intensity $(25 \%$,

$1065 \mu \mathrm{mol}$ photons $\mathrm{m}^{-2} \mathrm{~s}^{-1}$ ) gave rise to higher maximum toxin content of DTX1 and OA

11 throughout the growth phase (Figs 2b, 2c, 2g, 2h; Table 2) and the greatest toxin

12 production rates of DTX1, OA and OA-D8 (Figs 3g, 3h, 3j).

13 A $4{ }^{\circ} \mathrm{C}$ control was included as part of the light experiment, and no significant difference in toxin content of $D$. acuminata was observed between the control and $6^{\circ} \mathrm{C}$ treatment. Although not significant, the greatest toxin content of PTX2 and higher production rates of OA, DTX1, and OA-D8 occurred when the North American strain of D. acuminata was grown at $4^{\circ} \mathrm{C}$ versus $6^{\circ} \mathrm{C}$. This increase suggests that low temperatures may enhance production and/or allow for more efficient cellular retention of the toxin in D. acuminata. In another strain of $D$. acuminata, PTX2 cell content increased with decreasing temperature, however, no observed relationship was found with OA or DTX1 cell content (Kamiyama et al. 2010). Alexandrium fundyense (Anderson et al., 1990) and 3 other toxin producing 
dinoflagellates (Ogata et al., 1989) showed an enhancement in toxin content when cultures were grown under stress from low temperatures.

\subsection{Prey availability and growth of $D$. acuminata}

Increased cell densities of D. acuminata coincided with conditions (light and temperature) that enhanced prey cell concentrations and/or the duration of prey availability.

Even though the D. acuminata growth rates were similar for all three light treatments $\left(\sim 0.20 \mathrm{~d}^{-1}\right)$, the $25 \%$ treatment led to the lowest maximum cell yield $(2,235$ cells $\cdot \mathrm{mL}^{-1}$ ) which was 400 to 600 fewer cells $\cdot \mathrm{mL}^{-1}$ than observed for the $100 \%$ and $50 \%$ treatments. The lower cell yield in the $25 \%$ light treatment coincided with the exhaustion of the Myrionecta prey on day 10 of the incubation, whereas the cultures exposed to the 50 and $100 \%$ light treatments had food available until day 12 (Fig. 2f). As such, the prey was likely responding to the reduced light conditions with slower growth and D. acuminata was, in turn, responding to reduced prey availability with a lower maximum cell density.

Similarly, M. rubra prey remained in the $4^{\circ} \mathrm{C}$ treatment for 21 days, leading to a greater maximum cell concentration $\left(4,218\right.$ cells $\left.\cdot \mathrm{mL}^{-1}\right)$ of $D$. acuminata than that observed in the $6^{\circ} \mathrm{C}$ treatment $\left(2,782\right.$ cells $\left.\cdot \mathrm{mL}^{-1}\right)$ where prey disappeared by day 12 . The differences in the final D. acuminata cell densities, as well as the prolonged period of exponential growth, can be ascribed to the prolonged enhanced availability of food prey at its preferred lower incubation temperature. 
Previous studies (Park et al. 2006; Kim et al. 2008, Riisgaard and Hansen, 2009,

2 Tong et al. 2010) have documented that prey abundance has a pronounced impact on

3 D. acuminata growth and that very limited growth occurs when no (or improper) prey

4 is available. Kim et al., (2008) found that D. acuminata growth rates increased with

5 increasing prey concentration with a maximum growth rate of $0.91 \mathrm{~d}^{-1}$. Our previous

6 observations (Tong et al. 2010) corroborate those of Riisgaard and Hansen (2009)

7 who stated that "maximum growth and ingestion rates of Dinophysis acuminata were

8 obtained at relatively high Mesodinium rubrum (= Myrionecta rubra) concentrations

$9 \quad\left(>1,000\right.$ M. rubrum $\left.\mathrm{mL}^{-1}\right) . "$

These results also confirm that food and light are both required for mixotrophic growth of $D$. acuminata, but light concentrations between 65 and $284 \mu \mathrm{mol}$ photons $\mathrm{m}^{-2} \mathrm{~s}^{-1}$ do not alter this rate. This is in agreement with the finding of Kim et al., 2008, who stated that D. acuminata is a Model IIIB (Stoecker 1998) "obligate mixotroph as it cannot grow in the absence of prey and light”. Laboratory studies of Park et al. (2006), Kamiyama and Suzuki (2009), and Riisgaard and Hansen (2009), which demonstrate the importance of prey availability and photosynthesis on the growth of D. acuminata, also support this finding. It is possible that light levels, below $65 \mu \mathrm{mol}$ photons $\mathrm{m}^{-2} \mathrm{~s}^{-1}$, may impact the division frequency of this North American strain of $D$. acuminata, as Kim et al. (2008) found a marked reduction in growth when light was reduced to $10 \mu \mathrm{E} \mathrm{m}^{-2} \mathrm{~s}^{-1}$ but witnessed relatively consistent growth rates of $D$. acuminata at light levels between $30-200 \mu \mathrm{E} \mathrm{m}^{-2} \mathrm{~s}^{-1}\left(\approx \mu \mathrm{mol}\right.$ photons $\left.\mathrm{m}^{-2} \mathrm{~s}^{-1}\right)$. Setälä et al. (2005) estimated that the light level for maximum photosynthetic carbon uptake 
2 photons $\mathrm{m}^{-2} \mathrm{~s}^{-1}$, in the absence the presumptive food prey organism, Mesodinium

3 rubrum (= Myrionecta rubra) which was excluded from their incubations by

4 pre-incubation filtration. These authors also found that rates of carbon uptake in the

5 dark were less than $10 \%$ of the maximum rates in their other treatments. Kim et al.

6 (2008), observed a slight initial increase in cell density of D. acuminata cultured in

7 the dark after two days of incubation, followed by no growth for 5 days and then a

8 decline in cell number. Our study did not show any evidence of growth of either $D$.

9 acuminata or M. rubra during the dark treatment even though limited grazing of the

prey by $D$. acuminata was observed when preserved cell count samples were

enumerated. It should be noted that the frequency of feeding cells was much reduced in the dark treatment as compared to cultures that were incubated on a light-dark cycle; feeding was identified by a tight association between the Dinophysis and M. rubra and the loss of cilia from the prey. M. rubra eventually disappeared by day 17 in the dark treatment, presumably due to both limited predation by $D$. acuminata and mortality as a result of being kept in complete darkness.

\section{Conclusions}

In summary, we have shown that OA, DTX1 and PTX2 cellular concentrations can be quantified but are variable in $D$. acuminata throughout its growth in batch culture. Toxin production is greatest during exponential phase, but is coupled to cell division, and thus toxin content remains constant during this growth phase. In plateau 
1 phase, cell division ceases but toxin production continues, leading to higher toxin

2 contents. Light intensity had an effect on growth rate and toxin content, however, this

3 threshold likely lies between 0 and $65, \mu \mathrm{mol}$ photons $\cdot \mathrm{m}^{-2} \cdot \mathrm{sec}^{-1}$, as we found no

4 significant difference in results of cultures grown at 65, 145 and $284 \mu \mathrm{mol}$

5 photons $\cdot \mathrm{m}^{-2} \cdot \mathrm{sec}^{-1}$. The possible effect of dissolved nutrients on growth rate and toxin

6 production was not a focus of this investigation but is the subject of concurrent work.

7

8

9

\section{Acknowledgements}

The authors would like to thank the Ministry of Education, People's Republic of China for financial support as a Grand Fostering Project (No. 707011) and thank the China Scholarship Council, the U.S. National Science Foundation and the Woods Hole Oceanographic Institution for their financial support. Funding was provided by NSF Grant OCE-0850421, the Ocean Life Institute at the Woods Hole Oceanographic Institution, and the Woods Hole Center for Oceans and Human Health through NSF grant OCE-0430724 and NIEHS grant 1 P50 ES012742. We also thank Dr. Jeremiah D. Hackett (Department of Ecology and Evolutionary Biology, University of Arizona, USA) who helped in the isolation of Dinophysis and Dr. Christopher Miles (Norway's National Veterinary Institute) and Dr. Michael Quilliam (NRC-Canada) for their generous gifts of PTX11 and OA-D8, respectively. 


\section{References}

Andersen, P., Benedicte, H., Emsholm, H., 1996. Toxicity of Dinophysis acuminata in

Danish coastal waters. In: Yasumoto, T., Oshima, Y. and Fukuyo, Y. (Eds), Harmful and Toxic Algal Blooms, IOC of UNESCO, Sendai, pp. 281-284.

Anderson, D. M., Kulis, D. M., Doucette, G. J., Gallagher, J. C., Balech, E., 1994.

Biogeography of toxic dinoflagellates in the genus Alexandrium from the northeastern United States and Canada. Marine Biology 120(3), 467-478.

Anderson, D. M., Kulis, D. M., Sullivan, J. J., Hall, S., Lee, C., 1990. Dynamics and physiology of saxitoxin production by the dinoflagellates Alexandrium spp. Marine Biology 104(3), 511-524.

Bravo, I., Fernández, M.L., Ramilo, I., Martínez, A., 2001. Toxin composition of the toxic dinoflagellate Prorocentrum lima isolated from different locations along the Galician coast (NW Spain). Toxicon 39: 1537-1545.

Cembella, A., 1989. Occurrence of okadaic acid, a major diarrheic shellfish toxin, in natural populations of Dinophysis spp. from the eastern coast of North America. Journal of Applied Phycology 1(4), 307-310. 
1 Campbell, L., Olson R.J., Sosik H.M., Abraham A., Henrichs D.W., Hyatt C.J.,

2 Buskey, E.J., 2010. First harmful Dinophysis (Dinophyceae, Dinophysiales) bloom in

3 the US is revealed by automated imaging flow cytometry. Journal of Phycology 46 (1),

$4 \quad 66-75$

6 FAO, 2004. Marine Biotoxins, FAO Food and Nutrition Paper, 80. Food and

7 Agriculture Organization of the United Nations, Rome, 278.

8

9 Fux, E., Bire, R., Hess, P., 2009. Comparative accumulation and composition of

lipophilic marine biotoxins in passive samplers and in mussels (M. edulis) on the West

Coast of Ireland. Harmful Algae 8, 523-537.

Granéli, E., Johansson, N., Panosso, R., 1998. Cellular toxin contents in relation to nutrient conditions for different groups of phycotoxins. In: Reguera, B., Blanco, J., Fernandez, M.L.,Wyatt, T. (Eds) Harmful algae. Xunta de Galicia and Intergovernmental Oceanographic Commission-UNESCO, Santiago de Compostela, Spain, pp 321-324.

Guillard, R. R. L., 1973. Division rates. In: Stein J. R. (Ed) Handbook of Phycological Methods; Culture Methods and Growth Measurements. Cambridge University Press, Cambridge, pp. 289-312. 
1 Gustafson, D. E., Stoecker, D.K., Johnson, M. D., Van Heukelem, W. F., Sneider, K.,

2 2000. Cryptophyte algae are robbed of their organelles by the marine ciliate

3 Mesodinium rubrum. Nature 405(6790), 1049-1052.

4

5 Hackett, J. D., Tong, M.M., Kulis, D.M., Fux, E., Hess, P., Bire, R., Anderson, D.M., 6 2009. DSP toxin production de novo in cultures of Dinophysis acuminata 7 (Dinophyceae) from North America. Harmful Algae 8, 873-879.

8

Hallegraeff, G.M., Lucas, I.A.N., 1988. The Marine Dinoflagellate Genus Dinophysis (Dinophyceae) - Photosynthetic, Neritic and Non-Photosynthetic, Oceanic Species. Phycologia 27 (1), 25-42.

Hallegraeff, G.M., Anderson D.M., Cembella A.D., 2003. Manual on Harmful Marine Microalgae, $2^{\text {nd }}$ ed. UNESCO.

Hessen, D.O., Færørvig, P.J., Andersen, T., 2002. Light, nutrients, and P: C ratios in algae: grazer performance related to food quality and quantity. Ecology 83 (7), 1886-1898.

Hoshiai Gen-ichi, T. S., Kamiyama T., Yamasaki M., Ichimi K., 2003. Water temperature and salinity during the occurrence of Dinophysis fortii and D. acuminata in Kesennuma Bay, northern Japan. Fisheries Science 69, 1303-1305. 
2 Jaén, D., Mamán, L., Domínguez, R., Martín, E. 2009. First Report of Dinophysis

3 acuta in culture. Harmful Algae News 39, 1-2.

4

5 Kamiyama, T., Suzuki, T., 2009. Production of dinophysistoxin-1 and pectenotoxin-2

6 by a culture of Dinophysis acuminata (Dinophyceae). Harmful Algae 8 (2), 312-317.

7

8 Kamiyama, T., Nagai, S., Suzuki, T., Miyamura, K. 2010. Effect of temperature on production of okadaic acid, dinophysistoxin-1, and pectenotoxin-2 by Dinophysis acuminata in culture experiments. Aquatic Microbial Ecology 60(2), 193-202.

Kim, S., Kang, Y. G., Kim, H. S., Yih, W., Coats, D. W., Park, M. G., 2008. Growth and grazing responses of the mixotrophic dinoflagellate Dinophysis acuminata as functions of light intensity and prey concentration. Aquatic Microbial Ecology 51(3), 301-310.

Koukaras, K., Nikolaidis, G., 2004. Dinophysis blooms in Greek coastal waters (Thermaikos Gulf, NW Aegean Sea). Journal of Plankton Research 26(4), 445-457.

Lee, J.S., Igarashi, T., Fraga, S., Dahl, E., Hovgaard, P., Yasumoto, T., 1989.

Determination of diarrhetic shellfish toxins in various dinoflagellate species. Journal of Applied Phycology 1(2), 147-152. 
2 Lindahl, O., Lundve, B., Johansen, M., 2007. Toxicity of Dinophysis spp. in relation

3 to population density and environmental conditions on the Swedish west coast.

$4 \quad$ Harmful Algae 6(2), 218-231.

5

6 MacKenzie, L., Beuzenberg, V., Holland, P., McNabb, P., Suzuki, T., Selwood, A.,

7 2005. Pectenotoxin and okadaic acid-based toxin profiles in Dinophysis acuta and

8 Dinophysis acuminata from New Zealand. Harmful Algae 4(1), 75-85.

10 Marshall, H.G., 1996. Toxin producing phytoplankton in Chesapeake Bay. Virginia 11 Journal of Science 47 (1), 29-38.

McCarron, P., 2008. Studies in the Development of Reference Materials for Phycotoxins, with

14 a Focus on Azaspiracids. PhD Thesis. University College Dublin, Ireland.

Masselin, P., Lassus, P., Bardouil, M., 1992. High-Performance

Liquid-Chromatography Analysis of Diarrhetic Toxins in Dinophysis spp. from the

French Coast. Journal of Applied Phycology 4(4), 385-389.

19

Nagai, S., Nitshitani, G., Tomaru, Y., Sakiyama, S., Kamiyama, T., 2008. Predation by the toxic dinoflagellate Dinophysis fortii on the ciliate Myrionecta rubra and observation of sequestration of ciliate chloroplasts. Journal of Phycology 44(4), 
1

2

3 Nishihama, Y., Miyazono, A., Watanabe, S., Nakashima, Y., 2000. Year to year

4 changes of the cell density of dinoflagellates Dinophysis spp. and the diarrhetic

5 shellfish toxin level in scallops off the north-west coast of Hokkaido, Japan. Scientific

6 Reports of Hokkaido Fisheries Experimental Station (58), 1-8. (In Japanese, with

7 English abstract)

8

9 Nishitani, G., Nagai, S., Sakiyama, S., Kamiyama, T. 2008a. Successful cultivation of the toxic dinoflagellate Dinophysis caudata (Dinophyceae). Plankton and Benthos Research 3(2), 78-85.

Nishitani, G., Nagai, S., Takano, Y., Sakiyama, S., Baba, K., Kamiyama, T. 2008b.

Growth characteristics and phylogenetic analysis of the marine dinoflagellate

Dinophysis infundibulus (Dinophyceae). Aquatic Microbial Ecology 52(3), 209-221.

Ogata, T., Ishimaru, T., Kodama, M., 1987. Effect of water temperature and light intensity on growth rate and toxicity change in Protogonyaulax tamarensis. Marine Biology 95 (2), 217-220.

Ogata, T., Kodama, M., Ishimaru, T. 1989. Effect of water temperature and light intensity on growth rate and toxin production in toxic dinoflagellates. In Okaichi, T., 
1 Anderson, D.M., Nemoto, T. (Eds), Red Tides: Biology, Environmental Science and

2 Toxicology. Elsevier, New York, pp.423-426.

3

4 Park, M. G., Kim, S., Kim, H. S., Myung, G., Kang, Y. G., Yih, W., 2006. First

5 successful culture of the marine dinoflagellate Dinophysis acuminata. Aquatic

6 Microbial Ecology 45, 101-106.

7

8 Parkhill, J., Cembella, A., 1999. Effects of salinity, light and inorganic nitrogen on

9 growth and toxigenicity of the marine dinoflagellate Alexandrium tamarense from northeastern Canada. Journal of Plankton Research 21 (5), 939-955.

Pizarro, G., Escalera, L., González-Gil, S., Franco, J.M., Reguera, B., 2008. Growth , behavior and cell toxin quota of Dinophysis acuta during a daily cycle. Marine Ecology Progress Series 353, 89-105.

Quilliam, M.A., Hardstaff, W.R., Ishida, N., McLachlan, J.L., Reeves, A.R., Rose, N.W., Windust, A.J., 1996. Production of Diarrhetic Shellfish Poisoning (DSP) toxins by Prorocentrum lima in culture and development of analytical methods. In:

Yasumoto, T., Oshima, Y., Fukuyo, Y. (Eds.). Harmful and Toxic Algal Blooms. IOC of UNESCO, Sendai, pp. 289-292. 
1 in the analysis of phycotoxins by liquid chromatography - mass spectrometry. In de

2 Koe, W.J., Samson, R.A., van Egmond, H.P., Gilbert J., Sabino, M. (Eds), Mycotoxins

3 and Phycotoxins in Perspective at the turn of the Millenium, Proceedings of the Xth

4 International IUPAC Symposium on Mycotoxins and Phycotoxins, 2000, Guaruja

5 (Brazil), pp,383-391.

6

7 Reguera, B., Marino, J., Campos, MJ., Bravos, I., Fraga, S., Carbonell, A. 1993.

8 Trends in the occurrence of Dinophysis spp. in Galician waters. In: Smayda, T.J.,

9 Shimizu, Y. (Eds). Toxic Phytoplankton Blooms in the Sea, Elsevier, Amsterdam. pp, $559-564$.

Rehnstam-Holm, A. S., Godhe, A., Anderson, D.M., 2002. Molecular studies of Dinophysis (Dinophyceae) species from Sweden and North America. Phycologia 41 (4), 348-357.

Rhee, G. Y., Gotham, I. J., 1981. The Effect of Environmental Factors on Phytoplankton Growth: Light and the Interactions of Light with Nitrate Limitation. Limnology and Oceanography. 26 (4), 649-659.

Riisgaard, K., Hansen, P. J., 2009. Role of food uptake for photosynthesis, growth and survival of the mixotrophic dinoflagellate Dinophysis acuminata. Marine 
$1 \quad$ Ecology-Progress Series 381, 51-62.

2

3 Setälä, O., Autio, R., Kuosa, H., Rintala, J., Ylostalo, P., 2005. Survival and

4 photosynthetic activity of different Dinophysis acuminata populations in the northern

$5 \quad$ Baltic Sea. Harmful Algae 4(2), 337-350.

6

7 Stoecker, D.K., 1998. Mixotrophy among Dinoflagellate. Journal of Eukaryotic

$8 \quad$ Microbiology 46 (4), 397-401.

9

10 Suzuki, T., Mitsuya, T., Matsubara, H., Yamasaki, M., 1998. Determination of pectenotoxin-2 after solid-phase extraction from seawater and from the dinoflagellate Dinophysis fortii by liquid chromatography with electrospray mass spectrometry and ultraviolet detection - Evidence of oxidation of pectenotoxin-2. Journal of Chromatography A 815 (1), 155-160.

Suzuki, T., Miyazono, A., Baba, K., Sugawara, R., Kamiyama, T., 2009. LC-MS/MS analysis of okadaic acid analogues and other lipophilic toxins in single-cell isolates of several Dinophysis species collected in Hokkaido, Japan. Harmful Algae, 8 (2), 233-238.

Tango, P., Butler, W., Lacouture, R., Goshorn, D., Magnien, R., Michael, B., Hall, S., Browhawn, K., Wittman, R., Beatty, W., 2004. An Unprecedented Bloom of 
1 Dinophysis acuminata in Chesapeake Bay. In: Steidinger, K. A., Landsberg, J. H.,

2 Tomas, C. R., Vargo, G. A. (Eds.). Harmful Algae 2002. Florida Fish and Wildlife

3 Conservation Commission, Florida Institute of Oceanography, and Intergovernmental

4 Oceanographic Commission of UNESCO.

6 Tong, M.M., Zhou, Q.X., Kulis, D. M., Jiang, T., Qi, Y., Anderson, D. M., 2010. The

7 culturing techniques and growth characteristics of Dinophysis acuminata and its prey.

8 Chinese Journal of Oceanology and Limnology. 28 (6), 1237-1246.

10 Usup, G., Kulis, D.M., Anderson, D. M.,1994. Growth and toxin production of the toxic dinoflagellate Pyrodinium bahamense var. compressum in laboratory cultures. Natural toxins 2, 254-262.

Yasumoto, T., 1990. Marine microorganisms toxins - an overview. In: Granéli, E.,

Sundstrom, B., Edler, L., Anderson, D.M. (eds). Toxic Marine Phytoplankton, Sweden, 1989. Elsevier, New York, Amsterdam, London. pp. 3-8.

Yasumoto, T., Oshima, Y., Sugawara, W., Fukuyo, Y., Oguri, H., Igarashi, T., Fujita, N., 1980. Identification of Dinophysis-Fortii as the Causative Organism of Diarrhetic Shellfish Poisoning. Bulletin of the Japanese Society of Scientific Fisheries 46 (11), 1405-1411. 
1 Fig. 1. Growth model for Dinophysis acuminata as defined for this study. EEP:

2 Early-Exponential Phase, MEP: Mid-Exponential Phase, LEP: Late-Exponential

3 Phase, EP: Early-Plateau Phase, MP: Mid-Plateau Phase, LP: Late-Plateau Phase

4

$5 \quad$ Fig. 2. Growth responses (2a, 2f) of D. acuminata and M. rubra prey and cellular

6 quotas of DSP toxins and PTX2 under multiple temperature $(2 \mathrm{a}-2 \mathrm{e})$ and light

7 conditions $(2 f-2 j)$. Toxin values were grouped within each growth phase (middle and

8 late exponential phase and early, middle, and late-plateau phase) for statistical

$9 \quad$ analysis as defined in Fig.1. ( $\mathbf{v}:$ D. acuminata, $\nabla:$ M. rubra, $4^{\circ} \mathrm{C}, 302 \mu \mathrm{mol}$

photons $\cdot \mathrm{m}^{-2} \cdot \mathrm{sec}^{-1}(100 \%$ light $) ;$ - : D. acuminata, $\square:$ M. rubra $, 6^{\circ} \mathrm{C}, 284 \mu \mathrm{mol}$

photons $\cdot \mathrm{m}^{-2} \cdot \mathrm{sec}^{-1}(100 \%$ light $) ;:$ D. acuminata, $\diamond:$ M. rubra $, 6^{\circ} \mathrm{C}, 145 \mu \mathrm{mol}$

photons $\cdot \mathrm{m}^{-2} \cdot \sec ^{-1}(50 \%$ light $) ; \Delta:$ D. acuminata, $\Delta:$ M. rubra, $6^{\circ} \mathrm{C}, 65 \mu \mathrm{mol}$

photons $\cdot \mathrm{m}^{-2} \cdot \sec ^{-1}(25 \%$ light $) ; \bullet:$ D. acuminata, $6^{\circ} \mathrm{C}$, dark; $\circ:$ M. rubra, $6^{\circ} \mathrm{C}$, dark).

Note, dual Y-axes in panels $2 \mathrm{a}$ and $2 \mathrm{f}$ are used to plot D. acuminata and $M$. rubra cell

densities. There are no error bars on the missing data points including: one of the

duplicate samples for the first three time points of $100 \%$ light $6^{\circ} \mathrm{C}$ treatment, the first

two time points of $50 \%$ light $6^{\circ} \mathrm{C}$ treatment, the first time point of $25 \%$ light $6^{\circ} \mathrm{C}$

treatment and the second time point of $100 \%$ light $4^{\circ} \mathrm{C}$ treatment

Fig. 3. Growth responses (3a, 3f) of D. acuminata (repeated from Fig. 2f), toxin concentration in the cultures $(3 \mathrm{~b}-3 \mathrm{e})$ and toxin production rates $\left(\mathrm{R}_{\mathrm{tox}}, 3 \mathrm{~g}-3 \mathrm{j}\right)$ under light conditions at $6^{\circ} \mathrm{C}$. Means are plotted. (-: D. acuminata, $6^{\circ} \mathrm{C}, 284 \mu \mathrm{mol}$ 
1 photons $\cdot \mathrm{m}^{-2} \cdot \sec ^{-1}(100 \%$ light $) ; \bullet:$ D. acuminata, $6^{\circ} \mathrm{C}, 145 \mu \mathrm{mol}$

2 photons $\cdot \mathrm{m}^{-2} \cdot \mathrm{sec}^{-1}(50 \%$ light $) ; \mathbf{A}:$ D. acuminata, $6^{\circ} \mathrm{C}, 65 \mu \mathrm{mol}$ photons $\cdot \mathrm{m}^{-2} \cdot \mathrm{sec}^{-1}(25 \%$

3 light)).

4

5 Fig. 4. Growth responses (4a) of D. acuminata (repeated from Fig. 2a) and cellular

6 production of DSP toxins and PTX2 $\left(\mathrm{R}_{\text {tox }}, 4 \mathrm{~b}\right)$ at $4{ }^{\circ} \mathrm{C}$. Mean values are plotted. Toxin

7 units of DTX1, OA and PTX2 were fg cell ${ }^{-1}$ day $^{-1}$, fg cell ${ }^{-1}$ day $^{-1}$ and pg cell ${ }^{-1}$ day $^{-1}$,

8 respectively. ( $\mathbf{~ : ~ D . ~ a c u m i n a t a , ~} 4^{\circ} \mathrm{C}, 302 \mu \mathrm{mol}$ photons $\cdot \mathrm{m}^{-2} \cdot \mathrm{sec}^{-1}(100 \%$ light $)$; $\square$ :

$9 \quad$ DTX1; O:PTX2; $\triangle$ : OA; $\nabla:$ OA-D8).

Note, dual Y-axes in panel $4 \mathrm{~b}$ are used to plot cellular production of OA-D8.

Fig. 5. Specific toxin production rates $\left(\mu_{\text {tox }}\right)$ for each toxin $\square$ : DTX1; $\circ:$ PTX2; $\Delta$ :

OA; $\nabla$ : OA-D8) vs specific growth rate $(\mu)$. Rates were calculated between mid-exponential phase to early plateau phase for all light treatments and temperature treatments. Toxin units of DTX1, OA, PTX2 and OA-D8 were fg $\mathrm{mL}^{-1} \mathrm{day}^{-1}, \mathrm{pg} \mathrm{mL}{ }^{-1}$ day ${ }^{-1}, \mathrm{fg} \mathrm{mL}^{-1}$ day $^{-1}$ and area $\mathrm{mL}^{-1}$ day $^{-1}$, respectively. Mean values were plotted.

Fig. 6. Relationship between the cellular content of DTX1(fg cell $\left.{ }^{-1}\right)$ and OA (fg cell $\left.{ }^{-1}\right)$ throughout the growth phase of $D$. acuminata. Mean values were plotted over all four treatments, excluding the dark incubation. 

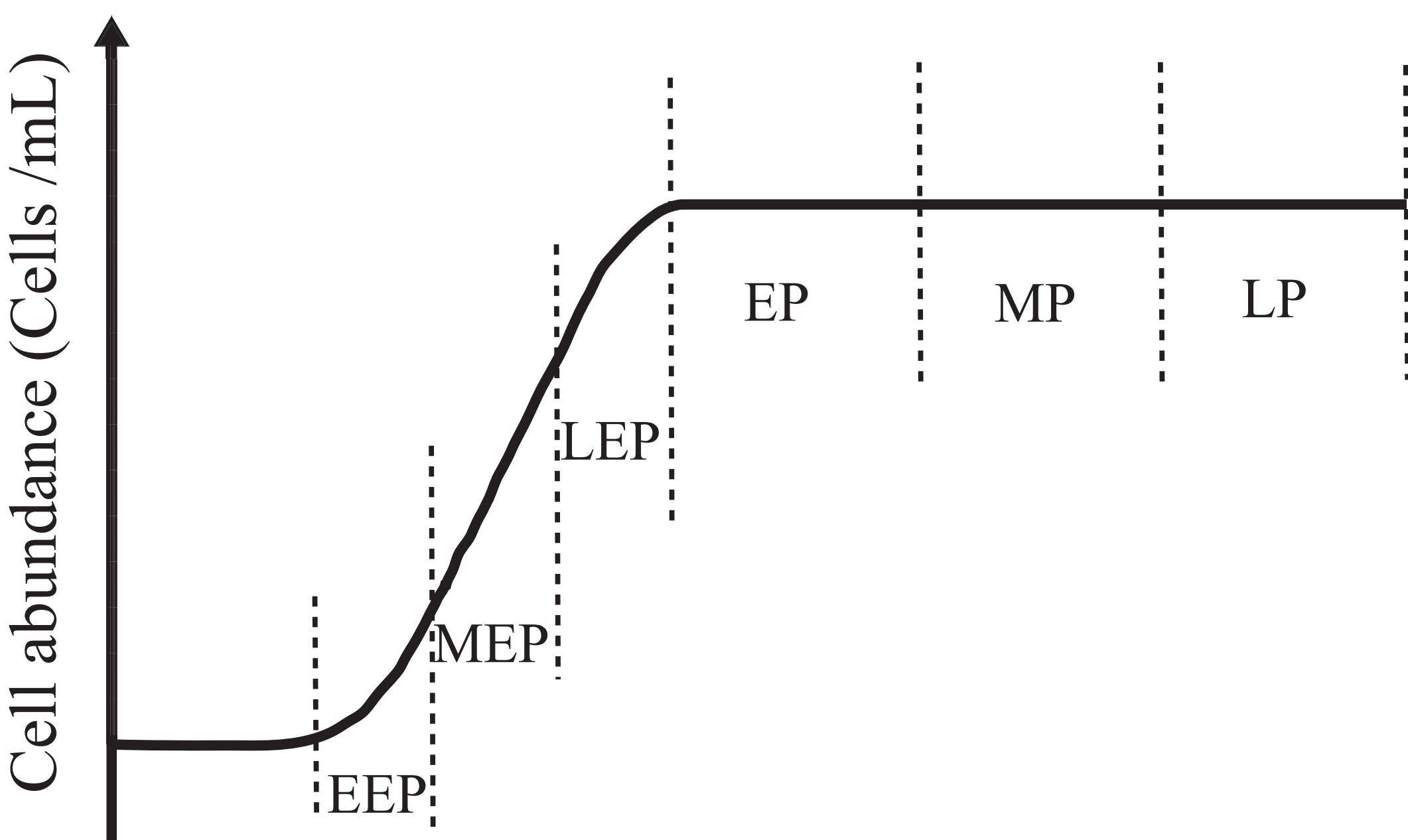
Figure 2

Click here to download high resolution image

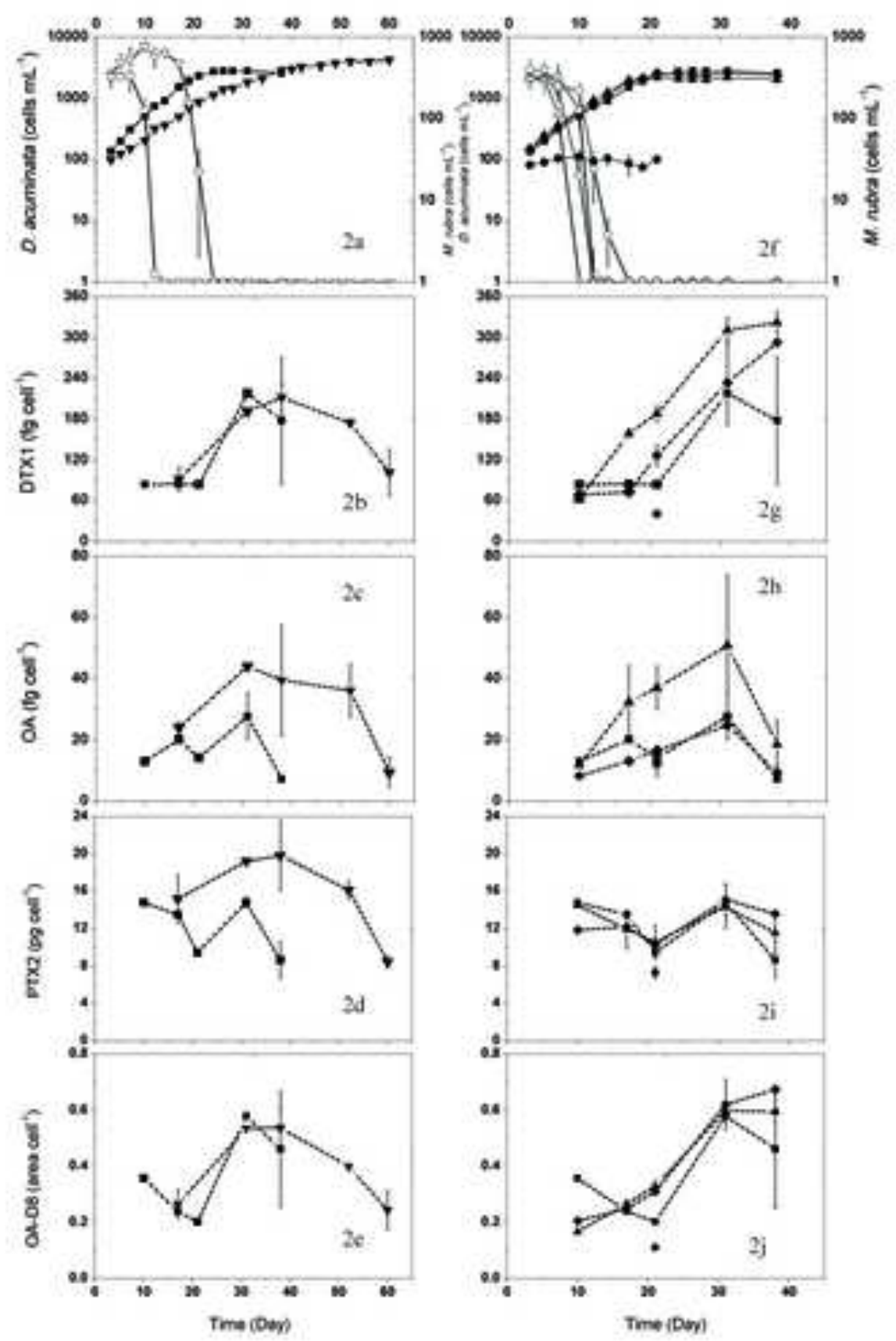


Figure 3
Click here to download high resolution image
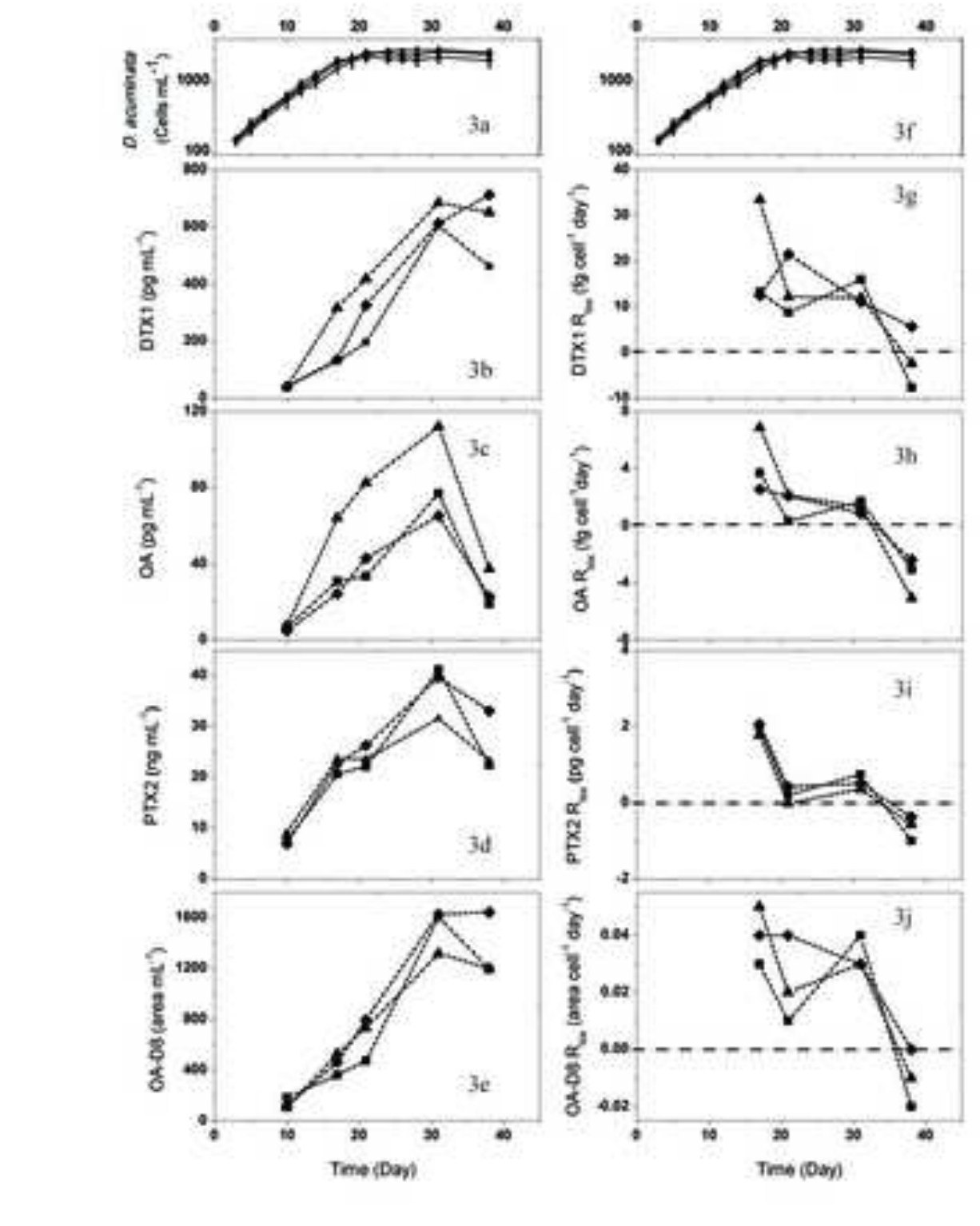

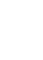




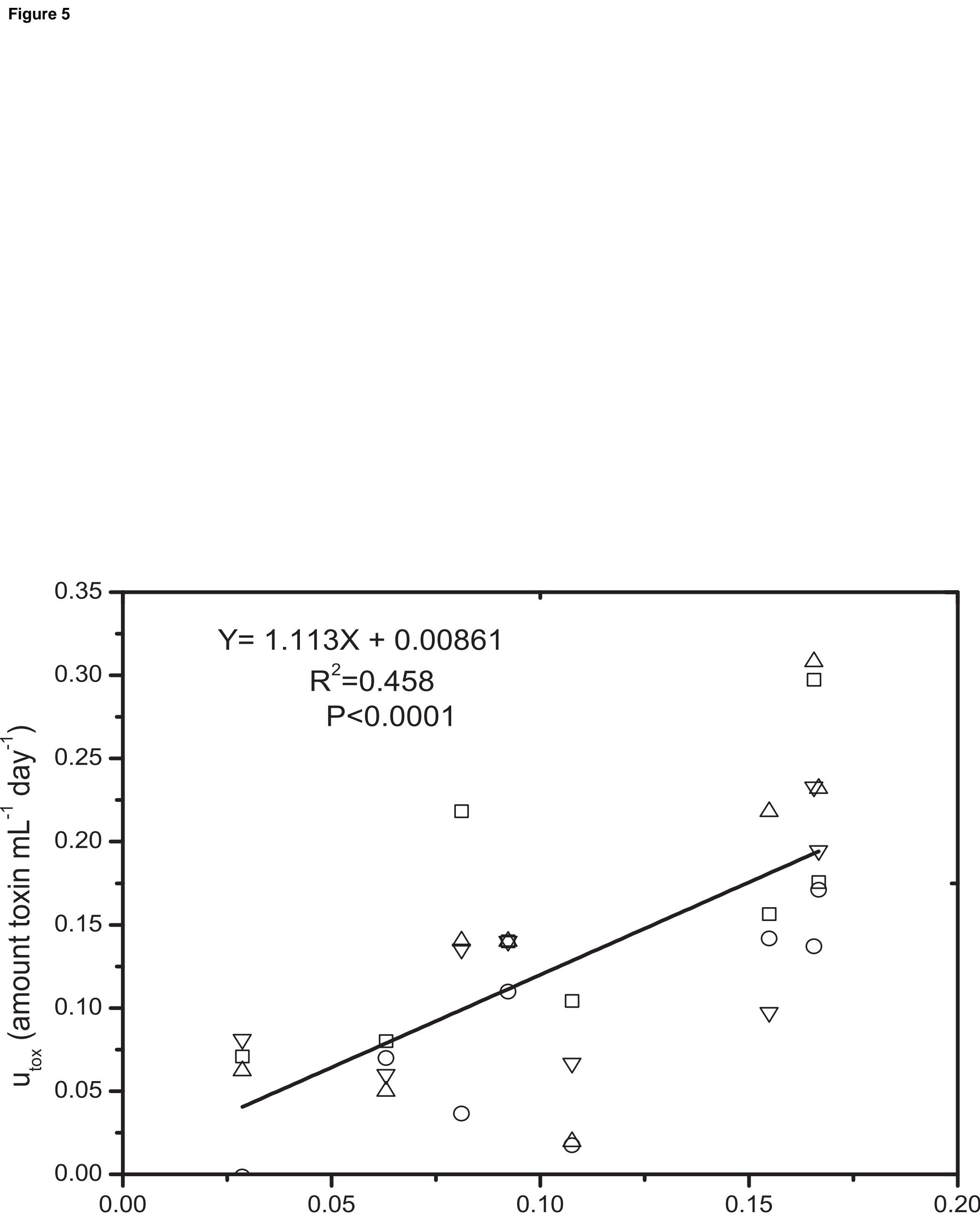

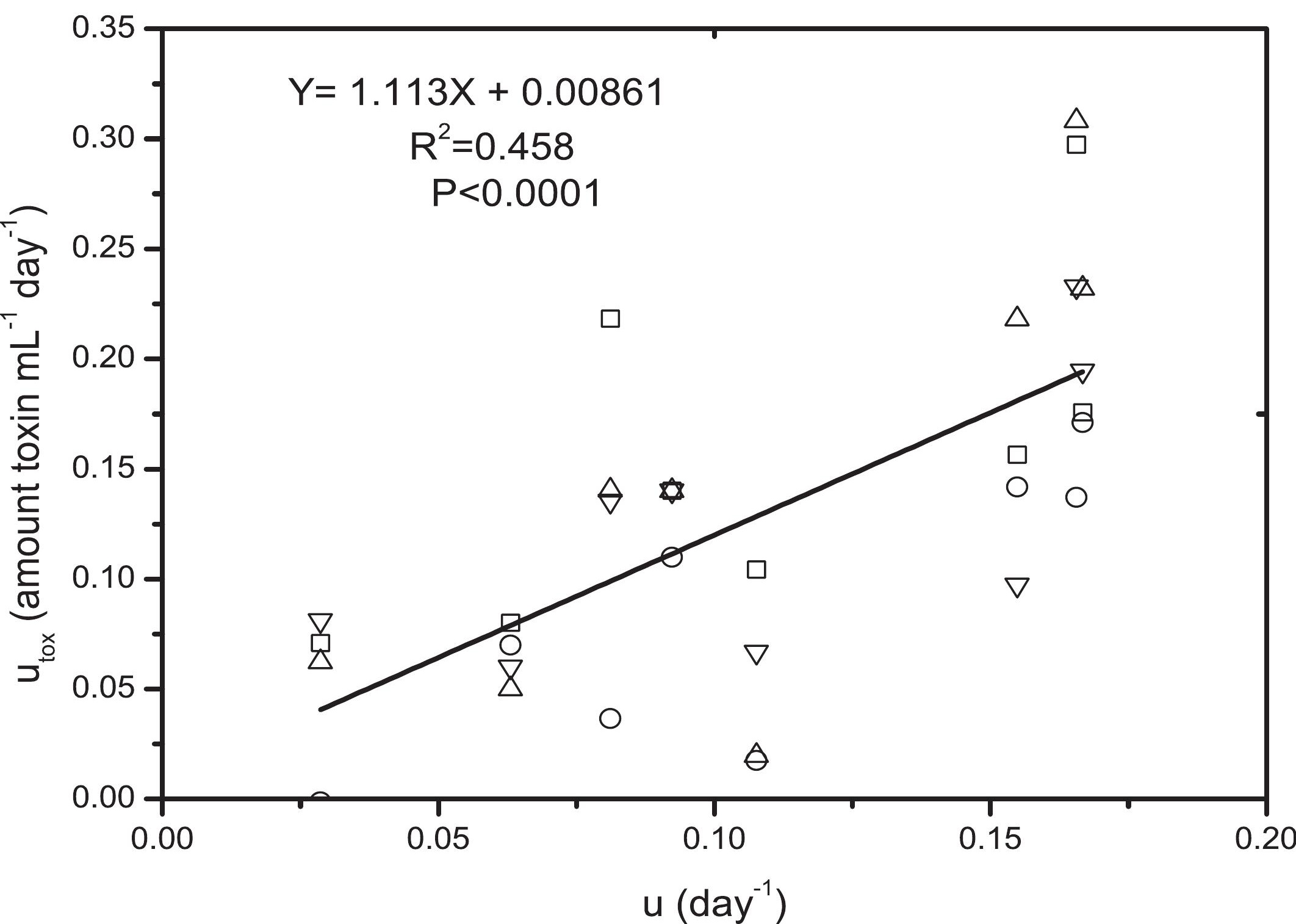

$u\left(\operatorname{day}^{-1}\right)$ 


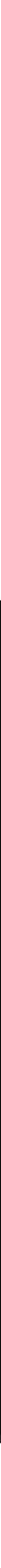

Figure 6

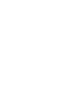

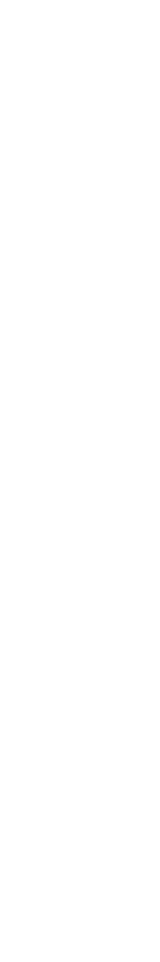

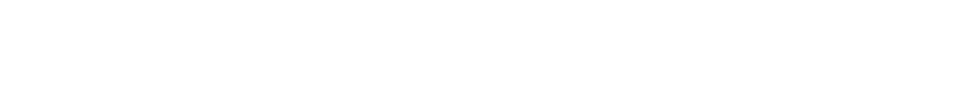

ran

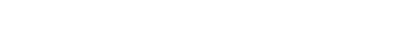

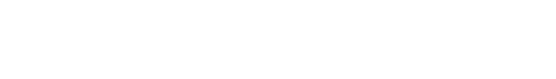
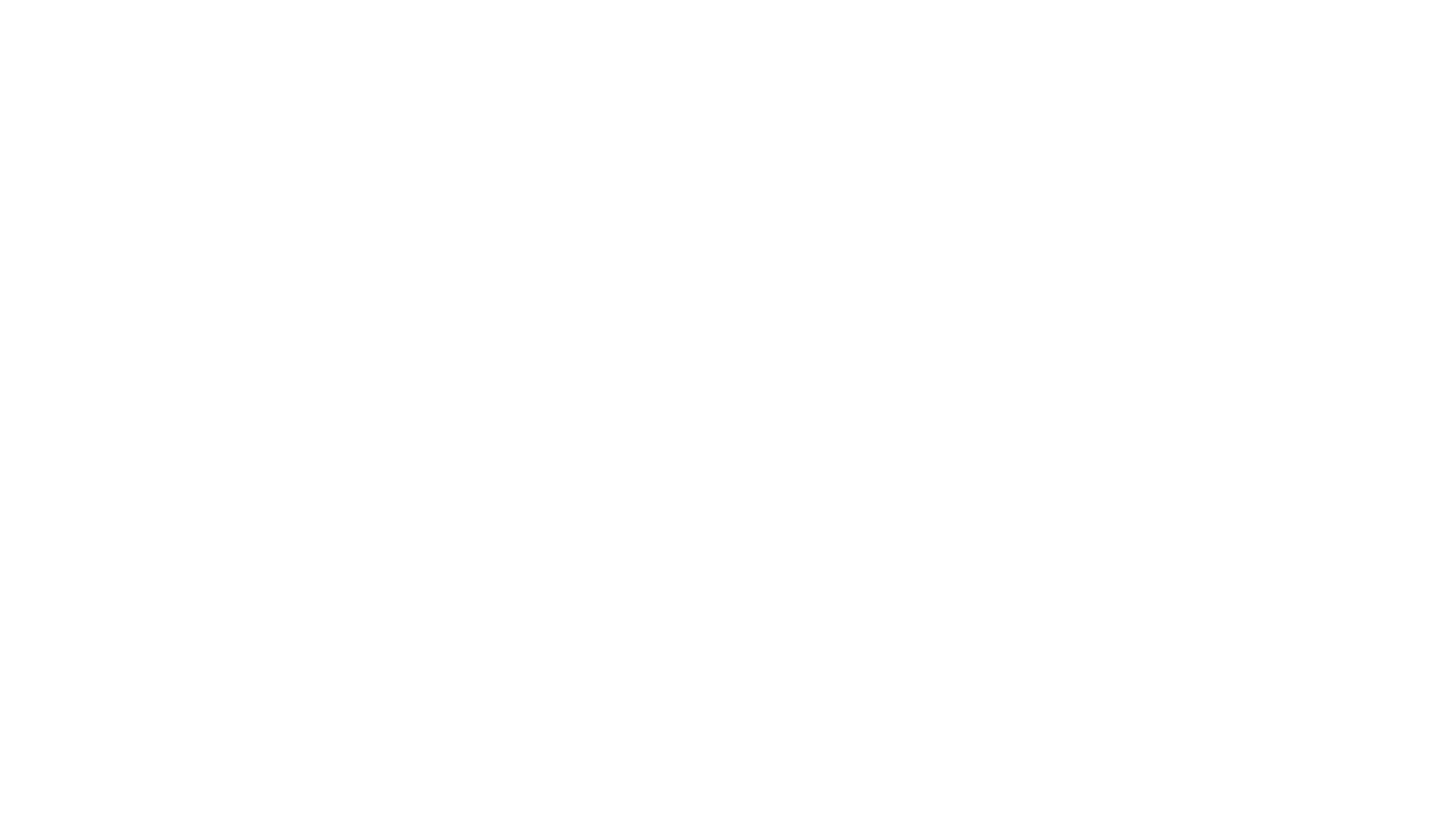
Table 1. Dinophysis acuminata culture conditions and associated growth rate measurements.

\begin{tabular}{ccccccccc}
\hline $\begin{array}{c}\text { Initial } D . \\
\text { acuminata } \\
\text { conc }\left(\mathrm{mL}^{-1}\right)\end{array}$ & $\begin{array}{c}\text { Initial } M \text {. } \\
\text { rubra } \\
\text { conc. } \\
\left(\mathrm{mL}^{-1}\right)\end{array}$ & $\begin{array}{c}\text { Temperature } \\
\left({ }^{\circ} \mathrm{C}\right)\end{array}$ & $\begin{array}{c}\text { Photoperiod } \\
(\mathrm{L}: \mathrm{D})\end{array}$ & $\begin{array}{c}\text { Light } \\
\text { conc. } \\
(\mu \mathrm{mol} \\
\text { photons } \\
\left.\mathrm{m}^{-2} \mathrm{~s}^{-1}\right)\end{array}$ & $\begin{array}{c}\text { Growth } \\
\text { Rate } \mu \\
\left(\mathrm{d}^{-1}\right)\end{array}$ & $\begin{array}{c}\text { Duration of } \\
\text { Exponential } \\
\text { Growth } \\
\left(\mathrm{d}^{-1}\right)\end{array}$ & $\begin{array}{c}\text { Batch or } \\
\text { Semi-continuous } \\
\text { growth }\end{array}$ & Reference \\
\hline 100 & 500 & 20 & Continuous & 60 & 0.91 & 3 & Batch & Park et al, 2006 \\
200 & 2000 & 20 & Continuous & 200 & 0.90 & 2 & Semi-continuous & Kim et al. 2008 (Long Term Growth Rates)* \\
200 & 2000 & 20 & Continuous & 10 & 0.40 & 2 & Semi-continuous & Kim et al. 2008 (Long Term Growth Rates)* \\
200 & 2000 & 20 & Continuous & 0 & 0.16 & 2 & Semi-continuous Kim et al. 2008 (Long Term Growth Rates)* \\
0.7 & 44 & 15 & $12: 12$ & 15 & $0.40-0.70$ & 23 & Batch & Kamiyama and Suzuki, 2009 \\
$40-60$ & $>1000$ & 20 & $14: 10$ & 100 & $0.39-0.51$ & n.a. & Batch & Riisgaard and Hansen, 2009 \\
100 & 2000 & 10 & $14: 10$ & 302 & 0.23 & 12 & Batch & Tong et al. In Press \\
100 & 2000 & 6 & $14: 10$ & 302 & 0.26 & 12 & Batch & Unpublished data \\
100 & 2000 & 6 & $14: 10$ & 284 & 0.19 & 17 & Batch & This study \\
100 & 2000 & 6 & $14: 10$ & 145 & 0.19 & 17 & Batch & This study \\
100 & 2000 & 6 & $14: 10$ & 65 & 0.21 & 17 & Batch & This study \\
100 & 2000 & 6 & Continuous & 0 & 0.00 & 0 & Batch & This study \\
100 & 2000 & 4 & $14: 10$ & 302 & 0.12 & 26 & Batch & This study \\
100 & 2000 & 4 & $14: 10$ & 302 & 0.11 & 24 & Batch & Tong et al. In Press \\
\hline
\end{tabular}

* Growth rates calculated during first 48 hrs of feeding cycle.

"n.a." denotes that the data were not available. 
Table 2. Cellular concentrations determined by LC-MS/MS of total toxins and ratio of OA/DTX1 and PTX2/ (OA+DTX1) under multiple temperature $\left(4\right.$ and $\left.6^{\circ} \mathrm{C}\right)$ and light conditions.

\begin{tabular}{|c|c|c|c|c|c|c|c|c|c|}
\hline & $\begin{array}{c}\text { Dinophysis } \\
\text { Cells/mL }\end{array}$ & $\begin{array}{l}\text { DTX1 } \\
\text { fg/cell }\end{array}$ & $\begin{array}{c}\mathrm{OA} \\
\mathrm{fg} / \text { cell }\end{array}$ & $\begin{array}{l}\text { PTX2 } \\
\text { fg/cell }\end{array}$ & $\begin{array}{l}\text { OA-D8 } \\
\text { Area/cell }\end{array}$ & $\begin{array}{c}\text { OA+DTX1 } \\
\text { fg/cell }\end{array}$ & OA/DTX1 & $\begin{array}{c}\text { PTX2/ } \\
(\mathrm{OA}+\mathrm{DTX} 1)\end{array}$ & $\begin{array}{c}\text { Total toxin } \\
\text { fg/cell }\end{array}$ \\
\hline \multicolumn{10}{|c|}{$100 \%-6^{\circ} \mathrm{C}$} \\
\hline 10 & 517 & 83.7 & 12.9 & 14754.6 & 0.4 & 96.6 & 0.15 & 152.7 & 14851.2 \\
\hline 17 & 1529 & 84.7 & 20.2 & 13472.5 & 0.2 & 104.9 & 0.24 & 128.4 & 13577.4 \\
\hline 21 & 2351 & 83.6 & 14.2 & 9404.3 & 0.2 & 97.8 & 0.17 & 96.2 & 9502.1 \\
\hline 31 & 2782 & 217.6 & 27.7 & 14785.9 & 0.6 & 245.3 & 0.13 & 60.3 & 15031.2 \\
\hline 38 & 2595 & 177.7 & 7.3 & 8631.3 & 0.5 & 185 & 0.04 & 46.7 & 8816.3 \\
\hline \multicolumn{10}{|c|}{$50 \%-6^{\circ} \mathrm{C}$} \\
\hline 10 & 580 & 68.6 & 8.3 & 11817.3 & 0.2 & 76.9 & 0.12 & 153.8 & 11894.2 \\
\hline 17 & 1863 & 73 & 13.1 & 12197 & 0.2 & 86.1 & 0.18 & 141.7 & 12283.1 \\
\hline 21 & 2578 & 126.4 & 16.6 & 10203.9 & 0.3 & 143 & 0.13 & 71.4 & 10346.9 \\
\hline 31 & 2629 & 233.3 & 24.8 & 15099.8 & 0.6 & 258.1 & 0.11 & 58.5 & 15357.9 \\
\hline 38 & 2436 & 292.7 & 9.3 & 13580.9 & 0.7 & 302 & 0.03 & 45 & 13882.9 \\
\hline \multicolumn{10}{|c|}{$25 \%-6^{\circ} \mathrm{C}$} \\
\hline 10 & 625 & 63.2 & 11.9 & 14507.9 & 0.2 & 75.1 & 0.19 & 193.2 & 14583 \\
\hline 17 & 1993 & 158.8 & 32.3 & 11897.3 & 0.3 & 191.1 & 0.20 & 62.2 & 12088.4 \\
\hline 21 & 2235 & 188 & 37 & 10561.5 & 0.3 & 224.9 & 0.20 & 47 & 10786.5 \\
\hline 31 & 2206 & 310.9 & 50.8 & 14338.1 & 0.6 & 361.7 & 0.16 & 39.6 & 14699.8 \\
\hline 38 & 2019 & 322.4 & 18.5 & 11509.8 & 0.6 & 340.9 & 0.06 & 33.8 & 11850.7 \\
\hline \multicolumn{10}{|c|}{$100 \%-4^{\circ} \mathrm{C}$} \\
\hline 17 & 504 & 91.9 & 24.1 & 15162.4 & 0.3 & 116 & 0.26 & 130.7 & 15278.4 \\
\hline 31 & 1834 & 191.5 & 44 & 19201.6 & 0.5 & 235.6 & 0.23 & 81.5 & 19437.2 \\
\hline 38 & 2852 & 211.6 & 39.5 & 19815 & 0.5 & 251.1 & 0.19 & 78.9 & 20066.1 \\
\hline 52 & 4016 & 174.3 & 36.1 & 16102.5 & 0.4 & 210.4 & 0.21 & 76.5 & 16312.9 \\
\hline 60 & 4218 & 101.3 & 9.4 & 8449 & 0.2 & 110.7 & 0.09 & 76.3 & 8559.7 \\
\hline
\end{tabular}


